\title{
Czech Countryside and Small Production Facilities
}

\author{
STUDENT Aleš ${ }^{1, a}$, NEDVĚD Martin ${ }^{2, b^{*}}$ \\ ${ }^{1,2}$ Faculty of Civil Engineering, VSB - Technical University of Ostrava, L. Podéště 1875, 70833 \\ Ostrava-Poruba, Czech Republic \\ aales.student@vsb.cz, ${ }^{\mathrm{b}}$ martin.nedved@vsb.cz
}

Keywords: Architecture, dominant, landscape, space, rural, production facilities

\begin{abstract}
Today, the small and medium-sized production facilities form a regular part of countryside. Many of them, however, lost their original function: they are abandoned, unattended, they dilapidate. As such, they have become a problem issue for villages and the country in general. No matter how slow and complicated there are solutions to this dire situation, nevertheless.
\end{abstract}

\section{Introduction}

Rural unlike the urban area is typical for its close connection with the natural order. Rural area is a cultural landscape created by people and by people maintained. It should be like that. However, this nature was being forgotten quite often during remote or recently past periods of the Czech history. Country should have approximated to and equate with a city, originally individual farming became communal, it was collectivized; not only fields but also villages were connected. Some villagers escaped to cities following the vision of more comfortable living, abandoned rural houses and cottages were bought by city people for the purposes of recreation, to escape from the overregulated and "restricted" city. But these people had mainly only a vague notion of rural life's natural rhythm and many of them were not able to join it, let alone to maintain meaningfully the village and landscape, which had been created by their predecessors who they were not related to, neither by blood nor by culture. Politics of the expulsion of Germans in the post-war period and later settlement by people from another parts of the republic had also a negative influence on the large rural areas in the Czech-German borderlands[1].

Until the industrialization of countryside in the second half of the 19th century, a church, a small church or a cemetery chapel was natural and often also the only dominant of a village and because villages pass through landscape and landscape flows into villages, we often perceive this dominant as a landscape element. Additional cultural and social point for many villages was the village square, or even the only street, where neighbours met, chat, offered guidance and cooperation. The local pub also played a role in the society communication [3].

Dominants with other than spiritual function, which the religious buildings performed, were increasing in number with the progress of industrialization of agricultural production and its intensification in the countryside. Extensive sites of state farms and agricultural cooperatives, small industrial estates, associated with the agricultural production, which were disproportionate with their scale to the area's rural structure, vertical dominants of tower silos, grain barns and other started to emerge in the rural landscape. But they seldom have been in harmony with the established landscape composition. Large number of the sites and vertical dominants has lost its original function; they are abandoned, not maintained, have ruined and are meaning a big problem for villages and rural landscape $[1,4]$. 

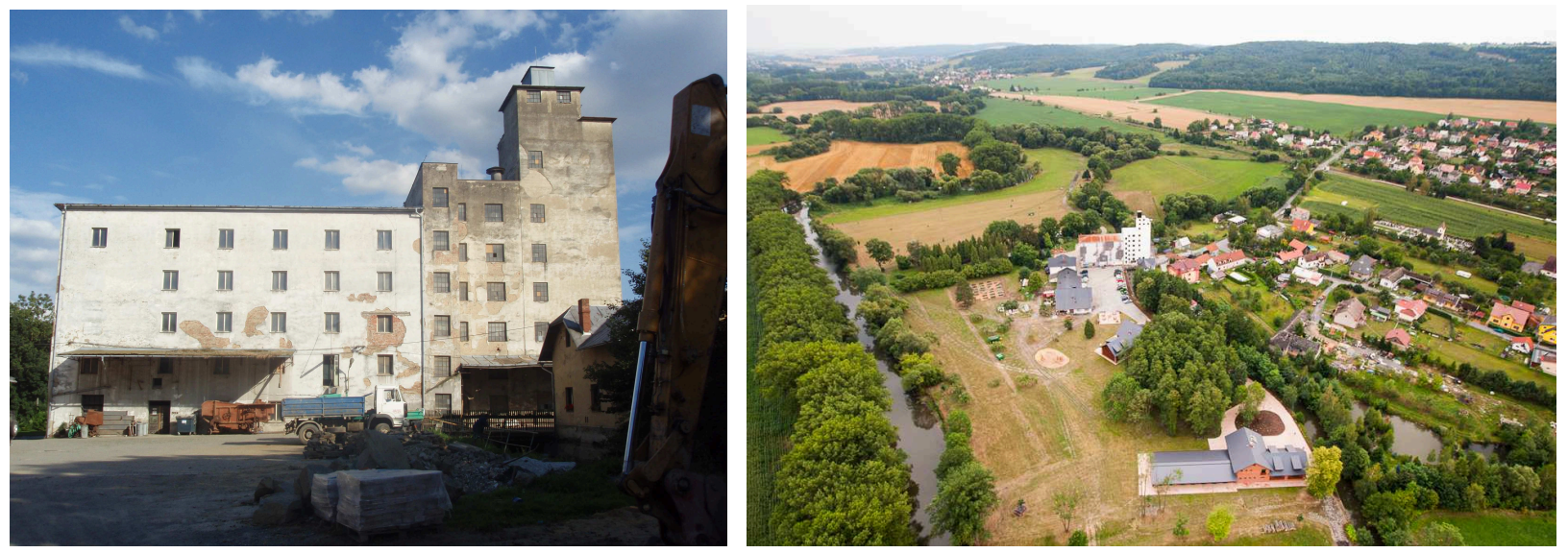

(Fig. 1: Former roller mill in Lhota u Opavy, Photo: A. Student, D. Bernard)

\section{Rural Industrial Heritage}

In principle, there are three possible ways of how to approach to the sites of inoperative farmsteads, sugar refineries, distilleries, dairies, lumber mills, brickfields, lime works buildings or mills. These are: demolition, conservation or adaptive re-use. Demolition is a radical, irreversible action, which is necessary to consider carefully and should be used only in case of buildings, which have never fit with their mass and scale in the landscape; optionally, in case of structures contaminated with chemical fertilizers or objects environmentally dangerous in another way. The opposite extreme is conservation - conservative method of monument preservation keeps the building in the last working day condition. However, this solution may be taken into consideration because of the economic reasons only in case of few buildings of an extraordinary historical and documentary value. The most rational and economically and architectonically advantageous way is an adaptive re-use of a building or site for some other function, which will vindicate its further existence and enable its survival in the village structure [1].

There are several options how to use industrial buildings in the rural area in a new way. The optimal solution, of course, is renewal of the original production with the use of modern technologies. This is possible in case of lumber mills, small breweries, distilleries or other buildings intended for agricultural products' processing. However, return to the original function is not possible anymore in many cases and it is necessary to adapt the object for a different function.

Production and Services. The most logical and universally beneficial solution is to use the object, in which dozens of employees worked, for the production and manufacturing purposes again (whether it applies to production line of light industry, manufacture, craftsman workshops or repair shop). Instead of lost job opportunities, the new ones will be created at the same place and the open farmland won't be taken for the other dull tin hall. Existing technical equipment network and connection to transport infrastructure may be incentive for the potential investors, however, adaptive re-use may be more expensive than a new building in the "industrial estate" founded on the greenfield land, paid from the public finances (of a city, state or European union) and using investment incentives in the form of tax relief or employment subsidies [2].

Housing. There are hundreds of well-done adaptive re-uses of industrial buildings reconstructed on housing in cities. Reconstruction of granaries and barns on individual housing is common in villages but the adaptive re-use of larger premises for collective living is still rare. However, there are many possible ways of how to do it - from the temporary accommodation within the scope of light tourism and agro-tourism, to start-up flats and social housing or assisted living homes for seniors, which would enable seniors to spend the rest of their lives in the village, where they were born, to luxurious loft-flats for primary and secondary living [2].

Cultural and Social Life of a Village. Many industrial objects have become an integral part of genius loci of a village and memory of a place. Thus, to use such buildings and premises for cultural 
purposes may be the suitable solution supporting the inhabitants' identification with their own village. Especially accumulation of functions (social hall for local inhabitants, restaurant, seat of local government, accommodation and services for tourists, other facilities and services for local community as well as for guests...) is optimal [2].

\section{Example}

An example of well-done adaptive re-use is a recently dilapidated compound of former roller mill in Lhota u Opavy. First reference to Lhota u Opavy appeared in 1413. Lhota u Opavy has been part of the municipality Háj in Silesia since 1979. This village can be typologically classified as Moravian countryside with good facilities. An important moment for Lhota u Opavy was opening of the railway route Svinov - Opava in 1855 and mainly construction of the station in 1923, which plays an important role for the Lhota's mill compound even today. Historical sources have been referring to this mill since 1460 . But an important break point in its history was in 1890, when Magdalena and Jan Havlíček leased the mill. The mill passed to their possession in 1894. Mr and Mrs Havlíček demolished the former thatched mill house with the lumber mill and built a brick single storey building, to which they built up one additional storey in 1911. Jan Havlíček replaced the mill wheel with the turbine in 1913, which supplied not even the mill but also the school, pub, railway station and other five cottages with electric power. Silo with building for grain-cleaning was additionally built in 1934. Company Havlíčkovy mlýny restored milling production after the period of Nazi administration of the Hlučín area and, in fact, did up and extended the mill in Lhota $u$ Opavy to the nowadays look. The mill was nationalized in 1948 and burned down on 17th April 1987; production was reduced, and the mill was used only for fodder mixing. The mill compound was falling into disrepair since that time; large part of the mill was inaccessible and served as a dump. Company MERKO, a.s., bought the whole compound of the mill in 2007 and launched the renovation.

Compound of the mill is situated in quite complicated area. Basically, it is an island between the meandering river Opava on the west, north and east and the mill race on the south. The bio-corridor passes the area and the border of the floodplain and geological structure of the bedrock (alluvial sediments) are also not very positive. However, quite quality technical infrastructure was built there in the past and also traffic accessibility is excellent thanks to the short distance from railway station and the road which connects Kravaře and Ostrava Poruba through Lhota.

One of the first steps made by the new owner was renovation and revitalization of the landscape structure, which had occurred in this area in the past. Mean to this aim was change of the local plan, which crowded-out business of disturbing character and agricultural land in favour of original meadow soils. Improper self-seeded tree species in the line along the river Opava, Reynoutria overgrown on the large area and also cultural crops growing in local farmland were eliminated. Long-life broad leaved trees and bushes, which improve protection of local fauna, were planted in harmonious composition. If we compare the aerial maps from years 2003 and 2014, it is obvious that this aim has been fulfilling successfully.

Another step was reconstruction of a small hydroelectric power station (vertical Francis turbine made in 1933), within which the flow profile was cleared and the bank of the mill race was reinforced; power generator and gears were changed, turbine impeller, vans and sluice-gate were overhauled.

This was followed by the reconstruction of some of the fully devastated buildings in the compound (f. e. reconstruction of electrical substation, new building of riding club with stables for 10 horses and garages for agricultural machinery on the original foundations of the farm building and stables, new building of guest house with sports equipment rentals on the foundation of residential building with outbuilding for farming purposes), by implementing of kitchen and hall into the partly burnt-out building of the mill and their opening for social events, by conversion of a 
part of the farm building into small village restaurant and refinement of existing hard surfaces for the purposes of farming and recreational and sport-touristic use of the premises.

Concrete silo building with grain-cleaning part, which has been a dominant in landscape visible on the way from Opava to Ostrava for 80 years, was also reconstructed. This building is used partly as a "Water goblin Sláma Museum", in which extant remains of grain milling technology are exhibited, supplemented by a small exposition introducing history of miller's trade in Opava region, mainly running of the local mill in Lhota. Self-supporting concrete spiral staircase was inbuilt into one of the silo's rooms, which will enable to use the building as an observation tower in future.

Absolute priority for the new compound owners was the restoration of the original landscape character step by step and natural integration of the devastated industrial premises into the rural environment while preserving the strong functionalistic expression of the silo building with the grain-cleaning part, which is not characteristic for rural area but enriches it in this case. It might be also because of the fact that mills functioned as places of "dissent" in the past; enlightened people, revivalists and patriots met there, they exchanged books and the millers themselves had a privileged position in the village society $[4,5]$.

\section{Summary}

It is obvious from the theoretical introduction and practical example that small production sites in the Czech rural area mean attractive but still little researched topic for architects. General rules for work with such buildings and premises can be formulated as follows:

Landscape. It is necessary to approach to revitalization of rural production sites in a boarder context; to consider urbanistic and compositional links and their incorporation into the village and landscape scenery.

Adaptive re-use. The best use of former production sites is to product in it again, optimally, in some of the related industry branches. Original production renewal may initiate restoration of original crops and so return of the landscape character, which was damaged during the collectivization of agriculture in the 1950s. It is reasonable to agree with the adaptive re-use only when there is not possible to resuscitate the original content.

Multifunctionality. Accumulation of several functions and investors, variety of activities and combination of private and public financing are advantageous from the point of view of economy of realization and further operation of the adaptively re-used premises. Combination of non-profit and profit-making activities is more sustainable in the future than a bet on one-branch grants.

Layering. It is not necessary to keep and maintain everything but it is better to consider all the connections and compositional relations before deciding for demolition. Extensions are often better than demolition.

Community. Stabilization and sustainability of the local community is more important than tourism. Tourism should be only addition to sustainable life of a village and its community.

\section{References}

[1] B. Blažek, Venkovy : anamnéza, diagnóza, terapie, Era, Brno, 2004.

[2] M. Nedvěd, V. Zámečníková. Využití industriálních staveb v Moravskoslezském kraji pro kulturní a společenské aktivity, in: Collective, Člověk, stavba a územní plánování 7, CTU, Prague, 2013, pp. 273-278.

[3] R. Perlín, S. Kučerová, Z. Kučera, A Typology of Rural Space in Czechia according to its Potential for Development., Geografie. 115 (No. 2) 161-187.

[4] A. Student, Válcový mlýn v části Lhota obce Háj ve Slezsku, in: M. Peřinková (Eds.), Techné Ostrava 2011: Industriální historické objekty a jejich současnost, Gasset, Prague, 2011, pp. 34-36.

[5] Information on http://mlyn.uslamy.cz/ 